\title{
Knowledge Attitude and Practices of Commercial Drivers Towards HIV/AIDS and Prevention in Ose Local Government Area Ondo State Nigeria
}

\author{
Article by Ebenezer Obi Daniel \\ Master of Public Health, Texila American University \\ Email: dannypressy@texilaconnect.com
}

\begin{abstract}
The presented article on 'Reducing bias in open-label trials where blinded outcome assessment is not feasible: strategies from two randomized trials' provides strategic approach towards creating unbiased approach were blinding in the study is not possible. The study has been supported by two randomized trials which have been well accepted before.
\end{abstract}

\section{Introduction}

The article for review is taken from 'Trials Journal' and the topic is 'Reducing bias in openlabel trials where blinded outcome assessment is not feasible: strategies from two randomized trials'. The review is mainly divided into Critical Review, conclusion and references.

\section{Critical Review}

Generally it is observed that blinding of the study involving devices, surgical interventions, non-pharmacological interventions are more difficult to blind as compared to traditional drug trials. It is necessary to use blinded outcome assessment to prevent bias in case of open study and this blinded outcome assessment requires use of independent clinician and independent adjudication committee. But there are instances were neither independent clinician presence nor adjudication committee is possible to bring blinded assessment. These have been explained in the given study 'Reducing bias in open-label trials where blinded outcome assessment is not feasible: strategies from two randomized trials’ by Brennan C Kahan. Single approach use for introducing blindness is by modification of outcome assessment definition. The approach has been explained by giving example of two randomized trials, TRIGGER Trial and TAPPS Trial.

However it is not always possible to modify the outcome assessment and thereby may be difficult to reduce bias in all open label study. A randomised trial can be methodologically sound and not be double blind or, conversely, double blind and not methodologically sound.

Although double blinding suggests a strong design, it is not the primary indicator of overall trial quality. Moreover, many trials cannot be double blinded. Such trials must, therefore, be judged on overall merit rather than an inapplicable standard based on double blinding. Methodological investigations tend to show that double blinding prevents bias but is less important, on average, in prevention of bias than is adequate allocation concealment.

Double blinding proves difficult or impossible in many trials. For instance, in general, surgical trials cannot be double blinded. Specifically, a trial that compares degrees of pain associated with sampling blood from the ear or thumb cannot be double-blinded. If researchers do not describe their trial as double-blind or the equivalent, it could still be scientifically strong. Apart from assessment of the other methodological aspects of the trial, readers would have to assess how much bias might have ensued due to absence of blinding. Readers should identify if anybody was blinded in the trial and what benefits might have accrued. 
South American Journal of Clinical Research

Special Edition 2016

\section{Conclusions}

Overall the article presents what it means by the topic itself. The two cited examples of the trials also justify what the author wants to convey to the reader. But still there are number of open label studies were blinding is not possible and chances of bias may remains.

\section{References}

[1]. Boutron I, Tubach F, Giraudeau B, Ravaud P, (2004): Blinding was judged more difficult to achieve and maintain in nonpharmacologic than pharmacologic trials, Journal of Clinical Epidemiology, vol 57(6), pg 543-550.

[2]. Chan AW , Tetzlaff JM , Gotzsche PC, Altman DG, Mann H, Berlin JA, Dickersin K, Hrobjartsson A, Schulz KF, Parulekar WR, Krleza-Jeric K, Laupacis A, Moher D, (2013): SPIRIT 2013 explanation and elaboration: guidance for protocols of clinical trials, Biomedical Journals, vol 346, pg 7586.

[3]. Dechartres A, Boutron I, Roy C, Ravaud P, (2009): Inadequate planning and reporting of adjudication committees in clinical trials: recommendation proposal, J Clin Epidemiol, vol 62(7), pg 695-702.

[4]. Dresler CM, Olak J, Herndon JE 2nd, Richards WG, Scalzetti E, Fleishman SB, Kernstine KH , Demmy T , Jablons DM, Kohman L, Daniel TM, Haasler GB, Sugarbaker DJ, (2005): Phase III intergroup study of talc poudrage vs talc slurry sclerosis for malignant pleural effusion, Chest, vol 127(3), pg 909-915.

[5]. Feagan BG, Sandborn WJ, D’Haens G, Pola S, McDonald JW , Rutgeerts P, Munkholm P, Mittmann U , King D, Wong CJ, Zou G, Donner A, Shackelton LM , Gilgen D, Nelson S, Vandervoort MK, Fahmy M, Loftus EV Jr, Panaccione R, Travis SP, Van Assche GA, Vermeire S, Levesque BG, (2013): The role of centralized reading of endoscopy in a randomized controlled trial of mesalamine for ulcerative colitis, Gastroenterology, vol 145(1), pg 149-157.e2.

[6]. Hrobjartsson A, Thomsen AS, Emanuelsson F, Tendal B, Hilden J, Boutron I, Ravaud P, Brorson S, (2012): Observer bias in randomised clinical trials with binary outcomes: systematic review of trials with both blinded and non-blinded outcome assessors, Biomedical Journals, vol 244, pg 1119

[7]. Hrobjartsson A, Thomsen AS, Emanuelsson F, Tendal B, Hilden J, Boutron I, Ravaud P, Brorson S, (2013): Observer bias in randomized clinical trials with measurement scale outcomes: a systematic review of trials with both blinded and nonblinded assessors, CMAJ, vol 185(4) pg E201 -E211.

[8]. Hrobjartsson A, Thomsen AS, Emanuelsson F, Tendal B, Rasmussen JV , Hilden J, Boutron I, Ravaud P, Brorson S (2014): Observer bias in randomized clinical trials with time-to-event outcomes: systematic review of trials with both blinded and nonblinded outcome assessors, Int J Epidemiol, vol 43(3), pg 937-948.

[9]. Jairath V , Kahan BC, Gray A, Dore CJ, Mora A, Dyer C, Stokes EA, Llewelyn C, Bailey AA, Dallal H, Everett SM, James MW, Stanley AJ, Church N, Darwent M, Greenaway J, Le Jeune I, Reckless I, Campbell HE, Meredith S, Palmer KR , Logan RF, Travis SP, Walsh TS, Murphy MF, (2013): Restrictive vs liberal blood transfusion for acute upper gastrointestinal bleeding: rationale and protocol for a cluster randomized feasibility trial, Transfus Med Rev, vol 27(3), pg 146-153.

[10]. Kahan BC, Jairath V, Murphy MF, Dore CJ, (2013): Update on the transfusion in gastrointestinal bleeding (TRIGGER) trial: statistical analysis plan for a clusterrandomised feasibility trial, Trials, vol 14, pg 06.

[11]. Linde K, Witt CM, Streng A, Weidenhammer W , Wagenpfeil S, Brinkhaus B, Willich SN, Melchart D, (2007): The impact of patient expectations on outcomes in four randomized controlled trials of acupuncture in patients with chronic pain, Pain, vol 128(3), pg 264-271

[12]. Noseworthy JH , Ebers GC, Vandervoort MK, Farquhar RE, Yetisir E, Roberts R , (1994): The impact of blinding on the results of a randomized, placebo-controlled multiple sclerosis clinical trial, Neurology, vol 44(1), pg 16-20.

[13]. Poolman RW, Struijs PA, Krips R, Sierevelt IN, Marti RK, Farrokhyar F, Bhandari M, (2007): Reporting of outcomes in orthopaedic randomized trials: does blinding of outcome assessors matter?, J Bone Joint Surg Am, vol 89(3), pg 550-558.

[14]. Putter H, Fiocco M, Geskus RB, (2007): Tutorial in biostatistics: competing risks and multi-state models. Stat Med, vol 26(11), pg 2389-2430. 
[15]. Schulz KF, Chalmers I, Hayes RJ, Altman DG, (1995): Empirical evidence of bias. Dimensions of methodological quality associated with estimates of treatment effects in controlled trials, The Journal of American Medical Association, vol 273(5), pg 408-412.

[16]. Savovic J, Jones HE, Altman DG, Harris RJ, Juni P, Pildal J, Als-Nielsen B, Balk EM , Gluud C, Gluud LL, Ioannidis JP , Schulz KF, Beynon R , Welton NJ, Wood L, Moher D, Deeks JJ, Sterne JA, (2012): Influence of reported study design characteristics on intervention effect estimates from randomized, controlled trials. Ann Intern Med, vol 157(6), pg 429-438.

[17]. Schulz KF, Grimes DA, (2002): Blinding in randomised trials: hiding who got what, Lancet, vol 359(9307), pg 696-700.

[18]. Thorpe KE, Zwarenstein M, Oxman AD, Treweek S, Furberg CD, Altman DG, Tunis S, Bergel E, Harvey I, Magid DJ, Chalkidou K, (2009): A pragmatic-explanatory continuum indicator summary (PRECIS): a tool to help trial designers, Journal of Clinical Epidemiology, vol 62(5), pg 464-475.

[19]. Tudur Smith C, Hickey H, Clarke M, Blazeby J, Williamson P, (2014): The trials methodological research agenda: results from a priority setting exercise Trials, vol 15(1), pg 32.

[20]. Villanueva C, Colomo A, Bosch A, Concepcion M, Hernandez-Gea V, Aracil C, Graupera I, Poca M, AlvarezUrturi C, Gordillo J, Guarner-Argente C, Santalo M, Muniz E, Guarner C, (2013): Transfusion strategies for acute upper gastrointestinal bleeding, $N$ Engl $J$ Med, vol 368(1), pg 11-21.

[21]. Wright S, Duncombe P, Altman DG, (2012): Assessment of blinding to treatment allocation in studies of a cannabis-based medicine (Sativex $(\mathrm{R})$ ) in people with multiple sclerosis: a new approach, Trials, vol 13, pg 189.

[22]. Wood L, Egger M, Gluud LL, Schulz KF, Juni P, Altman DG, Gluud C, Martin RM, Wood AJ, Sterne JA, (2008): Empirical evidence of bias in treatment effect estimates in controlled trials with different interventions and outcomes: meta-epidemiological study, BMJ, vol 336(7644), pg 601 -605. 